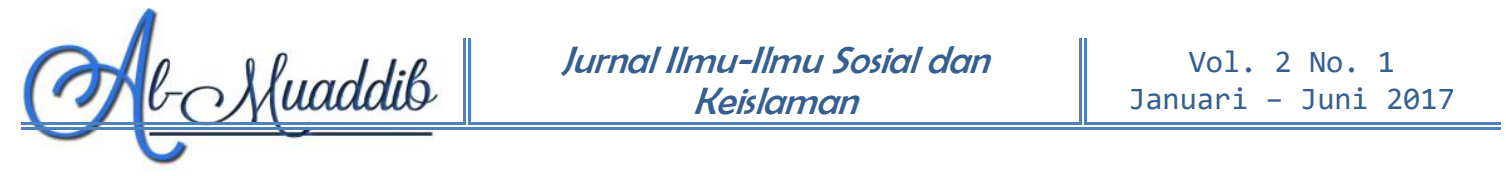

\title{
PEMBINAAN NARAPIDANA ANAK DI LEMBAGA PEMASYARAKATAN KELAS 2 B PADANGSIDIMPUAN
}

\author{
Nurhamidah Gajah \\ THE LECTURER OF FISIP UMTS \\ e-mail: mnuhamidah@yahoo.co.id
}

\begin{abstract}
The purpose of this research was to find out the founding of Child Prisoner in Class $2 \mathrm{~B}$ of Prison in Padangsidimpuan, and the constraint and solution of the jailer to the child prisoner. The method used was descriptive method with analysis approach qualitative descriptive while the technique of the collecting data through observation, interview, and document analysis.

Moreover, the result of this research can be concluded that the founding of Child Prisoner in Class 2B of Prison in Padangsidimpuan is still far from the expectation, it showed from 2 programs in class $2 \mathrm{~B}$ of LAPAS Padangsidimpuan that were not running well. There was some founding that were not executed successfully for child prisoner such as the self management and behavioral founding. They only have religion founding.

The constraints of the founding are the lack of facility to support the founding program and also the lack of official to guide the prisoner. To solve the problem, LAPAS start to build the facility and renovate the whole infrastructure of Class 2B Lapas Padangsidimpuan and make some agreements with Satpol PP Padangsidimpuan to back up the lack of the official in Lapas Padangsidimpuan.
\end{abstract}

\section{Keyword: Fouding, child prisoner, Lapas}

\section{A. PENDAHULUAN}

Negara Indonesia mempunyai dasar hukum yang berlandaskan pancasila. Pancasila menjadi suatu tolak ukur dari aspek kehidupan berbangsa dan bernegara, termasuk pelaksanaan hukum positif sejak dari proses penyidikan, pengadilan serta pemberian sanksi atau pemidanaan. Pancasila juga merupakan landasan utama dari sistem pemasyarakatan yang menerapkan adanya keseimbangan dan keselarasan baik dalam hidup manusia sebagai pribadi dalam hubungannya dengan masyarakat, alam, lingkungan dan Allah SWT. 


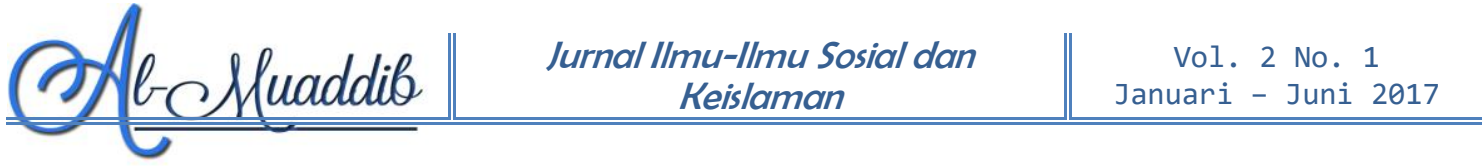

Pemasyarakatan adalah kegiatan untuk melakukan pembinaan yang merupakan bagian akhir dari sistem pemidanaan dalam tata peradilan pidana, pemasyarakatan juga merupakan perwujudan dari pelembagaan reaksi formal masyarakat terhadap kejahatan. Reaksi masyarakat ini awalnya hanya menitik beratkan pada unsur pemberian derita pada pelanggar hukum, sejalan dengan perkembangan masyarakat maka unsur pemberian derita tersebut harus diimbangi dengan perlakuan yang manusiawi dengan memperhatikan hak-hak asasi pelanggar hukum sebagai mahluk individu maupun mahluk sosial.

Dalam melaksanakan pemasyarakatan, tentu hal ini bukan saja merupakan tugas dari institusi pemasyarakatan melainkan juga tugas dari pemerintah dan masyarakat, dalam Undang-Undang Nomor 12 Tahun 1995 tentang Pemasyarakatan pasal 1 Ayat (2) menentukan bahwa

Sistem pemasyarakatan adalah suatu tatanan mengenai arah dan batas serta cara pembinaan warga binaan pemasyarakatan berdasarkan pancasila yang dilaksanakan secara terpadu antara Pembina, yang dibina, dan masyarakat untuk meningkatkan kualitas warga binaan pemasyarakatan agar menyadari kesalahan, memperbaiki diri, dan tidak mengulangi tindak pidana sehingga dapat diterima kembali oleh lingkungan masyarakat, dapat aktif berperan dalam pembangunan, dan dapat hidup secara wajar sebagai warga yang baik dan bertanggung jawab. ${ }^{1}$

Ketentuan dimaksudkan untuk meningkatkan kualitas warga binaan pemasyarakatan agar menyadari kesalahanya, memperbaiki diri dan tidak mengulangi kesalahannya sehingga dapat kembali kepada masyarakat, dalam proses pembinaan ini tentunya pemerintah juga harus memperhatikan pembinaan narapidana anak. Anak merupakan bagian terpenting yang tidak dapat terpisahkan dari keberlangsungan

1Undang-Undang nomor 12 Tahun 1995 Tentan Pemasyarakatan Pasal 1 Ayat 2 


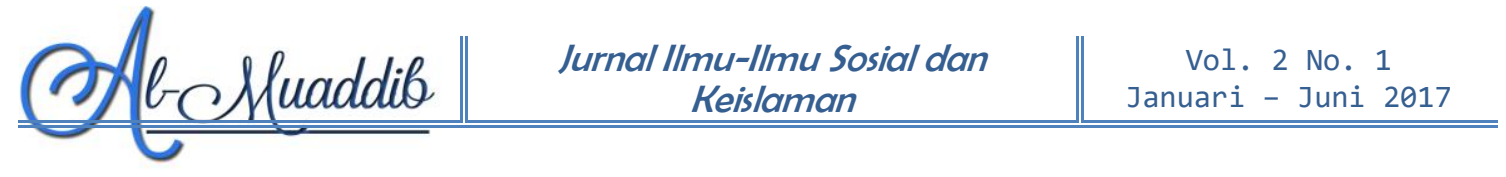

sebuah negara. Pentingnya peran anak ini, dalam UUD 1945 Pasal 28 B Ayat (2) telah disebutkan bahwa "Setiap anak berhak atas kelangsungan hidup, tumbuh dan berkembang serta berhak atas perlindungan dari kekerasan dan diskriminasi."2

Di saat ini pemerintahan Indonesia menunjukan komitmennya dalam memperhatikan anak dan memberikan perlindungan terhadap anak dengan dibentuknya kementerian tentang perlindungan anak yang jelas termuat di Perpres Republik Indonesia Nomor 59 Tahun 2015 pasal 1 ayat (1) dan (2), yaitu "Kementerian pemberdayaan perempuan dan perlindungan anak berada di bawah dan bertanggung jawab kepada presiden, kementerian pemberdayaan perempuan dan perlindungan anak dipimpin oleh menteri."3

Berdasarkan asas pembinaan tersebut pembinaan ini sangat berkaitan dengan perbaikan mental anak-anak. Anak yang bersalah pembinaannya ditempatkan di LAPAS anak, dipisahkan sesuai dengan stasus mereka masing-masing, yaitu anak pidana, anak negara dan anak sipil. LAPAS sebagai ujung tombak pelaksansaan asas pengayoman merupakan tempat untuk mencapai tujuan tersebut di atas melalui pendidikan, rehabilitasi dan reintegrasi. Namun dalam hal ini LAPAS Kelas 2 B Padangsidimpuan bukan merupakan LAPAS anak tetapi merupakan LAPAS Umum yang di dalamnya ada narapidana perempuan, dewasa dan anak-anak. LAPAS Salambue merupakan lembaga satu-satunya yang berada di Kota Padangsidimpuan

Dalam Undang-Undang Nomor 23 Tahun 2002 tentang Perlindungan Anak Perlindungan Khusus bagi anak yang berhadapan dengan hukum sebagaimana dimaksud dalam pasal 59 ayat (2) huruf b bahwa: "pemisahan dari orang dewasa"4. LAPAS Kelas 2 B Kota Padangsidimpuan bukan merupakan LAPAS Khusus Anak, tetapi

2UUD 1945 Pasal 28 B Ayat 2

3Perpres Republik Indonesia nomor 59 tahun 2015 Tentang Kementrian Pemberdayaan Perempuan dan Perlindungan Anak Pasal 1 Ayat 1 dan 2

${ }^{4}$ Undang-Undang Nomor 23 Tahun 2002 Pasal 59 Ayat 2 huruf $b$ 


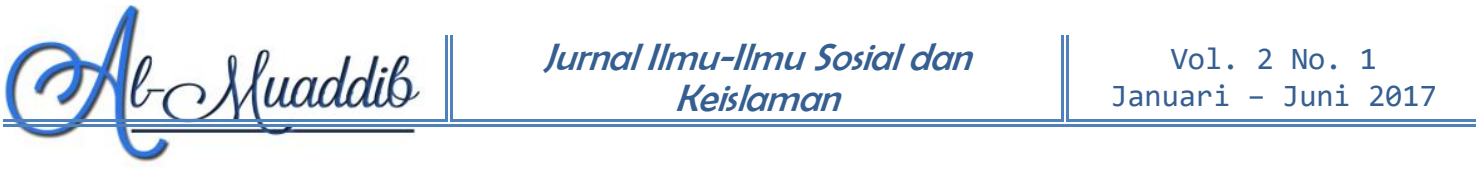

merupakan Lembaga Pemasyarakatan Umum, namun Narapidana Anak ada di lapas tersebut berjumlah 9 orang.

Narapidana anak dipisahkan dari narapidana dewasa sehingga mereka ditempatkan di Blok Anak. Bimbingan kerohanian keagamaan meliputi baca Alquran melaksanakan proses belajar mengajar di LAPAS dengan tenaga pengajar yang didatangkan dari luar LAPAS dan juga dari dalam LAPAS sehingga kegiatan belajar mengajar dapat secara efisien dilakukan. Bimbimngan Konseling terhadap anak dilakukan agar mereka menyadari kesalahan-kesalahan yang telah diperbuat. Bimbingan konseling ini dilakukan oleh Lapas bekerja sama dengan beberapa perguruan tinggi di Kota Padamgsidimpuan dan Kementerian Agama, di samping itu kegiatan yang ada di Lapas Kelas 2 B Padangsidimpuan bagi narapidana anak meliputi bidang olahraga seperti senam pagi dan futsal.

Terkait dengan hal tersebut, peneliti tertarik untuk membuat penelitian tentang bagaimana Pembinaan Narapidana Anak di Lembaga Pemasyarakatan Kelas 2 B Padangsidimpuan" kendala yang dihadapi oleh petugas LAPAS, serta upaya yang dilakukan oleh petugas LAPAS.

\section{B. KERANGKA TEORI}

\section{Defenisi Pembinaan}

Pembinaan berasal dari kata "bina" yang artinya "membangun, mendirikan, mengusahakan agar mempunyai kemajuan lebih."5. Pembinaan sering dikaitkan dalam suatu proses perbaikan atau sistem dan cara merubah sesuatu kearah yang lebih baik dan bermakna. Miftah Thoha mengatakan: bahwa "Pembinaan adalah suatu tindakan, proses, hasil atau pernyataan menjadi lebih baik."6 Dalam Peraturan Pemerintah Republik Indonesia Nomor 31 Tahun 1999 tentang Pembinaan dan Pembimbingan Warga Binaan Pemasyarakatan Pasal 1

${ }^{5}$ M.B. Ali, T. Deli, Kamus Lengkap Bahasa Indonesia, Penabur Ilmu, Bandung, 2000, hal. 82

${ }^{6}$ Miftah Thoha, Pembinaan Organisasi, Rajawali Pers, Jakarta,2004, hal. 7 
Ayat (1) menyebutkan bahwa "Pembinaan adalah kegiatan untuk meningkatkan kualitas ke taqwaan kepada Tuhan yang Maha Esa, Narapidana dan Anak didik Pemasyarakatan."7

Pembinaan itu bisa berupa suatu tindakan, proses, atau pernyataan dari suatu tujuan dan pembinaan itu juga bisa menunjukkan kepada perbaikan atas sesuatu. Pembinaan mempunyai hubungan yang erat dengan keluarga terutama terhadap hubungan orang tua dan anak, orang tua atau wali atau pengasuh yang akan menerima anak untuk dididik itu memiliki kemampuan untuk melakukan tugas:

a. Memberikan pembinaan mental atau spiritual dengan baiknya.

b. Sanggup memenuhi keperluan finasialnya sebagai biaya pendidikan

c. Sanggup member perhatian dan kasih sayang sepenuhnya. ${ }^{8}$

Tanggung jawab pembinaan dan pelaksanaan pembinaan kepada anak bukan semata hanya tanggung jawab dari keluarga seperti dikatakan didalam buku Majda El Muhtaj bahwa: "Pembinaan kesejahteraan anak termasuk pemberian kesempatan untuk mengembangkan haknya, pelaksanaan tidak saja merupakan tanggungjawab orang tua, keluarga, bangsa dan Negara melainkan di perlukan juga peran kerjasama internasional."9

Uraian di atas dapat dilihat bahwa pembinaan anak khususnya merupakan tanggungjawab yang begitu besar dan menjadi tanggungjawab bersama, baik ketika dalam permasalahan hukum seperti dikatakan bahwa: "Ketidak dewasaan fisik dan mentalnya, anak membutuhkan perlindungan hukum yang tepat, baik sebelum maupun setelah kelahiran."10 Dalam peran pembinaan yang berkaitan dengan

7 Peraturan Pemerintah Nomor 31 Tahun 1999 Tentang Pembinaan dan Pembimbingan warga Binaan Pemasyrakatan Pasal 1 Ayat 1

8 Sudarsono, Kenakalan Remaja, Rineka Cipta, Jakarta, 2012, hal. 30

9 Majda El Muhtaj, Dimensi-Dimensi HAM, PT RajaGrafindo Persada, Jakarta, 2008, hal. 227

10 Ibid, hal. 229. 
hukum maka asas pembinaan tetap menjadi hal yang penting, walaupun disaat seseorang menjalani hukuman.

Dalam Peraturan Pemerintah Nomor 31 Tahun 1999 tentang Pembinaan dan Pembimbingan Warga Binaan Pasal 6 Ayat (1) (2) dan (3) disebutkan Lapas mempunyai tanggungjawab pembinaan yaitu:

1. Kepala Lapas wajib melaksanakan pembinaan Narapidana

2. Dalam melaksanakan pembinaan sebagaimana dimaksud dalam Ayat (1), kepala Lapas wajib mengadakan perencanaan, pelaksanaan dan pengendalian atas kegiatan dan program pembinaan

3. Kegiatan pembinaan sebagaimana dimaksud dalam Ayat (2) diarahkan pada kemampuan Narapidana untuk berintegrasi secara sehat dengan masyarakat. ${ }^{11}$

Berdasarkan uraian di atas, dapat disimpulkan bahwaa pembinaan adalah suatu bentuk usaha yang didalamnya ada proses dalam perbaikan kearah yang lebih baik dari pada sebelumnya.

\section{Pengertian Narapidana}

Narapidana merupakan suatu bahasa yang erat kaitannya dengan dunia hukum, di dalam kamus hukum arti narapidana adalah: “Orang yang menjalani pidana dalam lembaga pemasyarakatan."12

Sedangkan menurut Bahasa Narapidana ialah: "Orang yang sedang menjalani Hukuman karena bersalah."13 Sedangkan menurut Undang-Undang Republik Indonesia Nomor 12 Tahun 1995 tentang Pemasyarakatan ialah: "Narapidana adalah Terpidana yang menjalani pidana hilang kemerdekaan di Lembaga Pemasyarakatan."14

Didalam hal ini, narapidana termasuk juga didalamnya anak pemasyarakatan, dalam Undang-Undang Republik Indonesia Nomor 12 Tahun 1995 Tentang pemasyarakatan Pasal I Ayat (8) dijelaskan mengenai anak didik pemasyarakatan ialah:

11 Op.Cit Peraturan Pemerintah Nomor 31 Tahun 1999 Tentang Pembinaan dan Pembimbingan warga Binaan Pemasyarakatan Pasal 6 Ayat 12 dan 3

12 Sudarsono, Kamus Hukum, PT. Asdi mahastya, Jakarta, 2009, hal. 293

13 Kamus Bahasa Indonesia, Pusat Bahasa Departemen Pendidikan Nasional, Jakarta, 2008, hal. 996

14 Undang-Undang Republik Indonesia Nomor 12 Tahun 1995 Tentang Lembaga Pemasyarakatan Pasal I Ayat 7 
1. Anak Pidana yaitu anak yang berdasarkan putusan pengadilan menjalani pidana di LAPAS Anak paling lama sampai berumur 18 (delapan belas) tahun.

2. Anak Negara yaitu anak yang berdasarkan putusan pengadilan diserahkan pada Negara untuk dididik dan di tempatkan di LAPAS Anak paling lama sampai berumur 18 (delapan belas) tahun

3. Anak Sipil yaitu anak yang atas permintaan orang tua atau walinya memperoleh penetapan pengadilan untuk dididik di LAPAS Anak paling lama sampai berumur 18 (delapan belas) tahun. ${ }^{15}$

Kata narapidana identik dengan orang yang telah menjalani suatu sanksi yang diberikan kepadanya dengan kata lain bisa juga dengan kata hukuman seperti dikatakan bahwa:

David J Cooke, Pamela J Baldwin, Jaqueline Hawison, narapidana ialah: "Para napi yang secara hukum telah ditetapkan bersalah, dicoba disadarkan kembali baik dengan hukuman maupun bimbingan agar dapat kembali di tengah masyarakat."16

Dari pernyataan tersebut dapat disimpulkan bahwa narapidana adalah orang yang sedang menjalani masa hukumannya di Lembaga Pemasyarakatan dimana sebagian kemerdekaannya dihilangkan dan mereka berhak atas pembinaan.

\section{Pengertian Anak}

Anak merupakan amanah yang diberikan oleh tuhan kepada manusia sebagai generasi penerus baik untuk penerus keluarga atau sekalipun untuk penerus bangsa, pengertian anak banyak di ungkapkan oleh Undang-Undang seperti Undang-Undang Nomor 3 Tahun 1997 tentang Pengadilan Anak Pasal 1 Ayat (1) bahwa: "Anak merupakan orang yang telah mencapai umur 8 (delapan) tahun sampai

15 Ibid, Pasal I Ayat 8

16 David J Cooke, Pamela J Baldwin, Jaqueline Hawison, Menyikap Dunia Gelap Penjara, PT Gramedia Pustaka Umum, Jakarta, 2008, hal. 1 


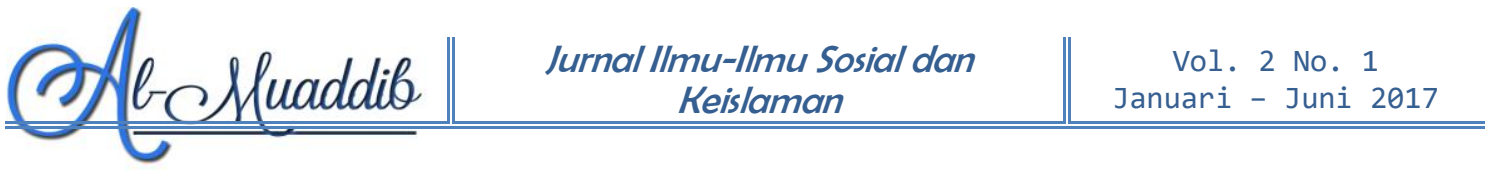

sebelum mencapai umur 18 (delapan belas) tahun dan belum pernah kawin."17

Undang-Undang Nomor 1 Tahun 1974 tentang Perkawinan Pasal 47 Ayat (1) bahwa: "Anak adalah belum mencapai umur 18 Tahun atau belum pernah melangsungkan perkawinan." 18 Undang-Undang Nomor 8 Tahun 1981 tentang KUHAP Pasal 171 bahwa: "Anak disidang pengadilan yang boleh diperiksa tanpa sumpah dipergunakan batasan umur dibawah 15 (lima belas) tahun."19 Undang-Undang Nomor 39 Tahun 1999 tentang Hak Asasi Manusia Pasal (1) Ayat 5 bahwa: "Anak adalah tiap manusia yang berusia dibawah 18 (delapan belas) tahun dan belum menikah, termasuk anak yang masih dalam kandungan."20 Undang-Undang Nomor 35 Tahun 2014 tentang Perlindungan Anak Pasal 1 Ayat (1) bahwa: "Anak adalah seseorang yang belum berusia 18 (delapan belas) tahun, termasuk anak yang masih dalam kandungan." 21 Peraturan Pemerintah Nomor 2 Tahun 1988 tentang Tata Usaha Kesejahteraan Anak bagi Anak yang Mempunyai Masalah bahwa: "Anak adalah seseorang yang belum mencapai umur 21 (dua satu) tahun atau belum kawin."22 Kitab Undang-Undang Hukum Perdata Pasal 330 bahwa: "Anak adalah mereka yang belum mencapai umur genap 21 (dua puluh satu) tahun dan belum kawin."23

Selanjutnya, mengenai landasan tentang anak dapat juga dilihat melalui:

Undang-Undang Nomor 12 Tahun 1995 Tentang Lembaga Pemasyarakatan Pasal 1 Ayat (8) Huruf a b dan c bahwa: "Anak didik Pemasyarakatan baik anak pidana, anak negara dan anak sipil untuk dapat di didik di Lapas Anak adalah paling lama sampai berusia 18 (delapan belas) tahun dan untuk anak sipil guna dapat ditempatkan di Lapas Anak maka perpanjangan penempatannya hanya boleh paling lama samapai berumur 18

17 Undang-Undang Nomor 3 Tahun 1997 Tentang Pengadilan Anak Pasal 1 Ayat 1

18 Undang-Undang Nomor 1 Tahun 1974 Tentang Perkawinan Pasal 47 Ayat 1

19 Undang-Undang Nomor 8 Tahun 1974 Tentang KUHP Pasal 171

20 Undang-Undang Nomor 39 Tahun 1999 Tentang Hak Asasi Manusia Pasal 1 Ayat 5

${ }^{21}$ Undang-UNdang Nomor 35 Tahun 2014 Tentang Perlindungan Anak Pasal 1 Ayat 1

22 Peraturan Pemerintah Nomor 2 Tahun 1988 Tentang Tata Usaha Kesejahteraan Anak bagi Anak yang Mempunyai Masalah

${ }^{23}$ Kitab Undang-Undang Hukum Perdata Pasal 330 
(delapan belas) tahun."24 Sedangkan di dalam bukunya El Muhtaj mengatakan bahwa: "Anak adalah manusia yang membutuhkan pemajuan dan perlindungan HAM." 25 Angger Sigit Pramurti dan Fuady Primaharsya, mengatakan: "Anak adalah amanah sekaligus karunia Tuhan Yang Maha Esa yang senantiasa harus kita jaga karena dalam dirinya melekat harkat, martabat dan hak-hak sebagai manusia yang harus dijungjung tinggi."26

Anak perlu mendapatkan perlindungan dari dampak negatif perkembangan dari cepatnya pembangunan zaman, komunikasi, teknologi, informasi, serta perubahan gaya dan cara hidup sebagian orang tua yang telah membawa perubahan sosial yang mendasar dalam kehidupan masyarakat yang sangat berpengaruh terhadap nilai dan prilaku anak, untuk itu penempatan anak harusnya dilakukan seperti yang dikatakan Imam Juhairi bahwa:

a. Anak diberi tempat khusus yang berbeda dunia dan kehidupanya sebagai orang dewasa

b. Anak memerlukan perhatian dan perlakuan khusus dari orang dewasa dan para pendidiknya. ${ }^{27}$

Dari pernyataan di atas dapat disimpulkan anak merupakan warisan dari bangsa yang wajib untuk dibina dan dididik sehingga dapat menjadi generasi penerus yang mempunyai akhlak yang bagus dan mampu untuk mengembangkan diri tanpa ada perusakan mental tumbuh dan berkembang dimasa-masa kecilnya.

\section{Pengertian Lembaga Pemasyrakatan}

Lembaga pemasyarakatan sebenarnya adalah suatu lembaga yang dahulunya di kenal sebagai rumah penjara, yakni dimana orangorang telah di jatuhi dengan pidana-pidana tertentu oleh hakim. Pasal 1 ayat (2) Undang-Undang Nomor 12 Tahun 1995 tentang

24 Undang-Undang Nomor 12 Tahun 1995 Tentang Lembaga Pemasyarakatan Pasal 1 Ayat 8 Op.cit

25 Majda El Muhtaj, Dimensi-Dimensi HAM, Op.cit. hal 229

26 Angger Sigit Pramukti dan Fuady Primaharsya, Sistem Peradilan Pidana Anak, Pustaka Yustisia, Yogyakarta, 2015, hal 1

27 Imam Juhairi, Perlindungan Hukum terhadap Anak dalam keluarga Poligami, Pustaka Bangsa, Jakarta, 2003, hal 81 
Pemasyarakatan yang di maksud dengan Sistem Pemasyarakatan adalah:

Suatu tatanan mengenai arah dan batas serta cara pembinaan Warga Binaan Pemasyarakatan berdasarkan Pancasila yang dilaksanakan secara terpadu antara terpadu Pembina, yang dibina, dan masyarakat untuk meningkatkan kualitas Warga Binaan Pemasyarakatan agar menyadari kesalahan, memperbaiki diri, dan tidak mengulangi tindak pidana sehingga dapat diterima kembali oleh lingkungan masyarakat, dapat aktif berperan dalam pembangunan, dan dapat hidup secara wajar sebagai warga yang baik dan bertanggung jawab. ${ }^{28}$

Tujuan diselenggarakannya Sistem Pemasyarakatan UndangUndang Nomor 12 Tahun 1995 adalah:

Dalam rangka membentuk Warga Binaan Pemasyarakatan agar menjadi manusia seutuhnya, menyadari kesalahan, memperbaiki diri, dan tidak mengulangi tindak pidana sehingga dapat diterima kembali oleh lingkungan masyarakat, dapat aktif berperan dalam pembangunan, dan dapat hidup secara wajar sebagai warga yang baik dan bertanggung jawab. ${ }^{29}$

Fungsi sistem pemasyarakatan menurut Undang-Undang Nomor

12 Tahun 1995 tentang Pemasyarakatan yaitu:

"Menyiapkan Warga Binaan Pemasyarakatan agar dapat berinteraksi secara sehat dengan masyarakat, sehingga dapat berperan kembali sebagai anggota masyarakat yang bebas dan bertanggun jawab."30 Lapas sebagai tempat pembinaan yang dilakukan mempunyai arti seperti disebutkan dalam UndangUdang Nomor 12 Tahun 1995 Tentang Pemasyarakatan: "Lembaga pemasyarakatan yang selanjutnya disebut LAPAS adalah tempat untuk melaksanakan pembinaan narapidana dan anak didik pemasyarakatan."31 Seperti dikemukakan David J Cooke, Pamela J Baldwin, Jaqueline Hawison, Lapas mempunyai makna bahwa: "Berperan memasyarakatkan kembali para Narapidana yang telah melanggar aturan hukum dan normanorma yang dianut dimasyarakat."32 Loc. cit

28 Undang-Undang Nomor 12 Tahun 1995 Tentang Lembaga Pemasyarakatan,

29 Ibid, Pasal 2

30 Ibid, Pasal 3

31 Ibid, Pasal 1 Ayat 3

33 David J Cooke, Pamela J Baldwin, Jaqueline Hawison, Op.cit, hal. 1 


\section{METODE PENELITIAN}

Lokasi penelitian ini dilaksanakan di Lembaga Pemasyarakatan Kelas 2 B Kota Padangsidimpuan. Jln. Lintas Sumatera Km. 7 No. 28 Telp. (0634) 21003. Selanjutnya metode penelitian adalah suatu pedoman bagi penulis bagaimana langkah- langkah yang akan dilakukan di dalam suatu penelitian. Adapun jenis penelitian yang dilakukan adalah metode penelitian kualitatif deskriptif.

Berikut ini merupakan sumber informasi:

\begin{tabular}{|l|l|l|}
\hline 1. & Ade Marito Siregar & PKM Anak \\
\hline 2. & Muhammad Alfian & PKM Anak \\
\hline 3. & Rudi Nasution & PKM Anak \\
\hline 4. & Panondangi Harahap & Narapidana Anak \\
\hline 5. & Milki Saputra Siregar & Narapidana Anak \\
\hline 6. & Hatta Mulia Siregar & Narapidana Anak \\
\hline 7. & Rudi Siregar & Narapidana Anak \\
\hline 8. & Liga Asrafi & Narapidana Anak \\
\hline 9. & Adreansyah & Narapidana Anak \\
\hline
\end{tabular}

Sumber: Data Olahan Penulis Tahun 2016

Sedangkan alat pengumpulan data penelitian ini menggunakan observasi, wawancara, dan dokumentasi.

\section{TEMUAN DATA DAN PEMBAHASAN}

Lembaga Pemasyrakatan Padangsidimpuan Sebelum tahun 1980-an bertempat dipusat Kota Padangsidimpuan, pada masa itu bangunan lembaga pemasyarakatan yang digunakan merupakan bangunan peninggalan Hindia Belanda dengan bangunan yang sudah tua dan memprihatinkan, ditambah lagi dengan kondisi sarana dan prasarana yang minim membuta Lembaga Pemasyarakatan tersebut sudah tidak layak digunakan sebagai tempat membina para warga Binaan Pemasyarakatan pada masa itu.

Kemudian pada tahun 1980 turunlah anggaran pemerintah untuk mendirikan gedung LAPAS yang baru menggantikan gedung LAPAS 


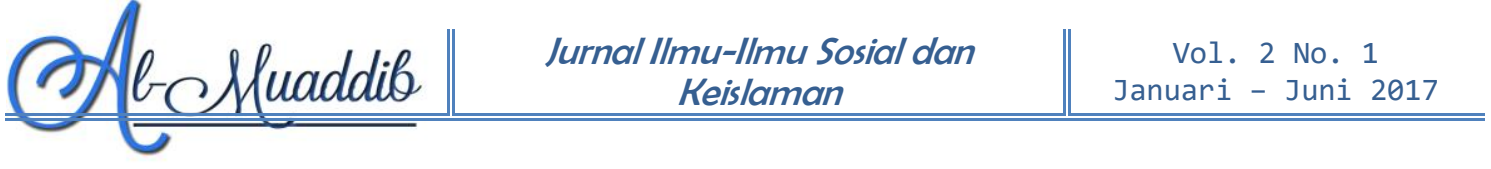

yang lama. Gedung tersebut merupakan bangunan gedung kantor permanen yang akan menjadi gedung LAPAS Kelas 2 B Padangsidimpuan nantinya.

Anggaran untuk membangun gedung LAPAS yang baru diperoleh pada tanggal 12 Maret 1980, tepatnya berada di atas tanah seluas $18.000 \mathrm{~m}^{2}$ yang terletak di Jalan Lintas Sumatera Km. 7 No. 28. Desa Purbatua Pijorkoling Kecamatan Padangsidimpuan Tenggara, Kota Padangsidimpuan, Propinsi Sumatera Utara.

Gedung tersebut selesai dibangun pada tahun 1986 dan ditempati 1984, dengn pimpinan M. Hatta Boehanuddin, kemudian bangunan lembaga yang telah selesai dibangun diresmikan oleh Radjo Harahap selaku kepala Kantor Wilayah Departemen Kehakiman Sumatera Utara tepatnya pada tanggal 13 Maret 1984.

Selanjutnya pada tahun 1986 ketika Lembaga Pemasyarakatan Padangsidimpuan dipimpin oleh Kobin Sipayung, Lembaga Pemasyarakatan Padangsidimpuan beralih menjadi Rumah Tahanan Negara Padangsidimpuan. Kobin Sipayung memimpin Lembaga Pemasyarakatan Kelas 2 B Padangsidimpuan selama 2 tahun yaitu dari tahun 1986 sampai tahun 1988. Kemudian Kobin Sipayung digantikann oleh Tulus Wijayanto, Bc. IP yang memimpin Lembaga Pemasyaraktan Kelas 2 B Padangsidimpuan selama \pm 7 tahun dimulai pada tahun 1988 sampai dengan tahun 1955.

Kemudian Tulus Wijayanto digantikan oleh Haviluddin yang memimpin Lembaga Pemasyarakatan tepatnya pada akhir tahun 1995 sampai tahun 1999. Setelah masa jabatan Haviluddin berakhir beliau digantikann oleh Surono beliau memimpin Lembaga Pemasyarakatan selama 4 tahun pada tahun 2000 sampai 2004.

Semasa kepemimpinan beliau Rumah Tahanan Negara Padangsidimpuan berubah kembali menjadi Lembaga Pemasyarakatan Kelas 2 B Padangsidimpuan. Kemudian pada akhir tahun 2004 Surono digantikan oleh Amran Silalahi yang memimpin selama 4 tahun yaitu 
dari akhir tahun 2004 sampai tahun 2008. Setelah masa jabatan Amran Silalahi berakhir beliau digantikan oleh Drs. Wawan Indiarto yang memimpin Lembaga Pemasyarakatan Kelas 2 B Padangsidimpuan selama \pm 1 tahun yaitu pada tahun 2008 sampai dengan tahun 2009 .

Kemudian pada akhir tahun 2009 setelah kepemimpinan Drs. Wawan Indiarto, Lembaga Pemasyarakatan Kelas 2 B Padangsidimpuan dipimpin oleh Sugeng Irawan \pm 2 tahun yaitu pada akhir tahun 2009 sampai pada tahun 2012, setelah masa kepemimpinan Sugeng Irawan berakhir kemudian digantikan oleh Mara Sutan Harahap yang memimpin Lembaga Pemasyarakatan Kelas 2 B Padangsidimpuan \pm 2 tahun dan setelah kepemimpinan Mara Sutan Harahap berakhir, pada tahun 2014 sampai dengan sekarang Lembaga pemasyarakatan dipimpin oleh Sarwono.

Letak Geografis LAPAS Kelas 2 B Padangsidimpuan LAPAS Kelas 2 B Padangsidimpuan dibangun dikota Padangsidimpuan tepatnya Jalan Lintas Sumatera Km. 7 No. 28 Desa Purbatua Pijorkoling Kecamatan Padangsidimpuan Tenggara Kota Padangsidimpuan Provinsi Sumatera Utara, dari pusat Kota Padangsidimpuan perjalanan menuju lokasi Lapas hanya memakan wakru cukup 30 menit. Dari jalan lintas menuju pintu masuk lembaga hanya memiliki jarak sekitar 100 meter. Adapun batas-batas wilayah:

1. Sebelah Timur berbatasan dengan lapangan sepak bola.

2. Sebelah Barat berbatasan dengan perkebunan masyarakat.

3. Sebelah Utara berbatasan dengan perkebunan masyarakat.

4. Sebelah Selatan berbatasan dengan rumah penduduk.

Ditinjau dari kelasnya, LAPAS Padangsdimpuan ini dikategorikan Kelas 2 B. Dari kelasnya diketahui bahwa penghuni dari lapas ini tergolong dalam kasus-kasus menengah ke bawah. Lain halnya dengan Lapas Nusa Kambangan dengan jelas Kelas 1 yaitu kelas kakap. Tahanannya di dalam Lapas adalah tahanan dengan kasus yang berat, seperti Teroris, pengedar narkoba jumlah besar dan kasus tinggi lainnya. Sarana dan prasarana untuk menunjang kelancaran proses 
pembinaan, lembaga pemasyaraktan kelas II B Padangsidimpuan dilengkapi dengan sarana dan prasarana pembinaan sebagaimana tercantum dalam tabel di bawah ini:

\begin{tabular}{|l|l|l|l|}
\hline No & Jenis & Jumlah & Keterangan \\
\hline $\mathbf{1}$ & $\mathbf{2}$ & $\mathbf{3}$ & $\mathbf{4}$ \\
\hline 1 & Ruang Perkantoran & 10 & Baik \\
\hline 2 & Rumah Dinas & 6 & Baik \\
\hline 3 & $\begin{array}{l}\text { Kamar Warga } \\
\text { Binaan }\end{array}$ & 34 & Baik \\
\hline 4 & Ruang Tamu & 1 & Baik \\
\hline 5 & Ruang Belajar & 1 & Baik \\
\hline 6 & Aula/Ruang Serba & 1 & Baik \\
\hline 7 & Guna & 1 & Baik \\
\hline 8 & WC Umum & 2 & Baik \\
\hline 9 & Dapur Umum & 1 & Baik \\
\hline 10 & Lapangan Olahraga & 1 & Baik \\
\hline 11 & Sumur & 3 & Baik \\
\hline 12 & Klinik & 2 & Baik \\
\hline 13 & Mesjid & 1 & Baik \\
\hline 14 & Gereja & 1 & Baik \\
\hline 15 & Perpustakaan & 1 & Baik \\
\hline 16 & Ruang bimbingan & 1 & Baik \\
\hline
\end{tabular}

Sumber: Data Sarana dan Prasarana Lembaga Pemasyarakatan Klas 2 Padangsidimpuan 
Adapun stuktur organisasi kepengurusan lembaga pemasyarakatan kelas II B Padangsidimpuan adalah sebagai berikut:

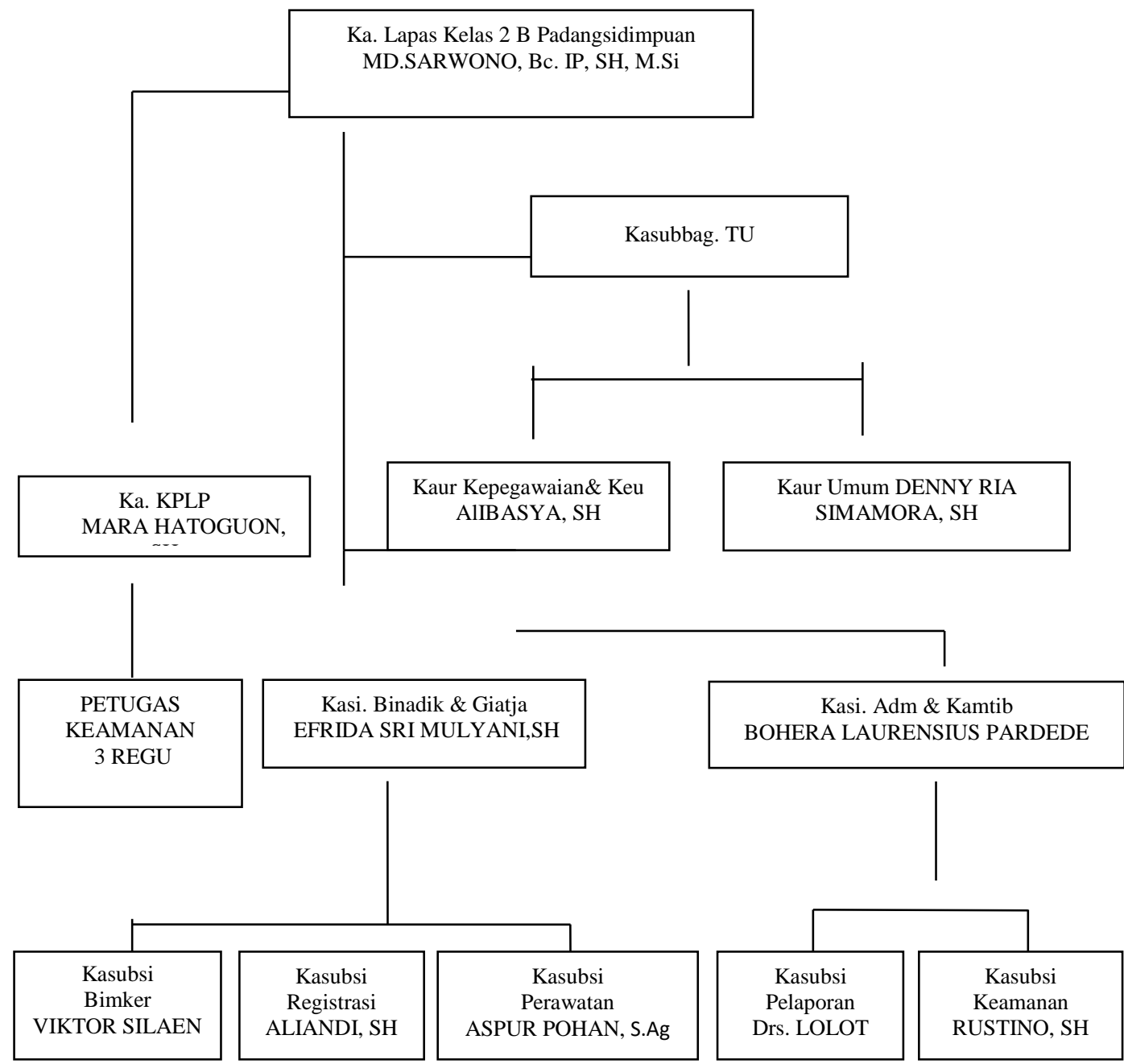

Sumber: Data Lembaga Pemasyarakatan Klas 2 B Padangsidimpuan

Keadaan dari warga binaan pemasyarakatan Kelas 2 B Padangsidimpuan yaitu sebagai berikut:

\begin{tabular}{|l|l|l|l|l|l|l|}
\hline \multirow{2}{*}{ No } & \multirow{4}{*}{ Golongan } & \multicolumn{3}{l|}{ Keadaan } & \multirow{2}{*}{ Jaki-laki } & \multicolumn{2}{l|}{ Wanita } \\
\cline { 3 - 7 } & & Dewasa & $\begin{array}{l}\text { Anak- } \\
\text { anak }\end{array}$ & Dewasa & $\begin{array}{l}\text { Anak- } \\
\text { anak }\end{array}$ & \\
\hline 1 & 2 & 3 & 4 & 5 & 6 & 7 \\
\hline 1 & Napi B I & 36 & 2 & - & - & 358 \\
\hline 2 & Napi B II a & 26 & 1 & 1 & - & 28 \\
\hline 3 & Napi B II b & - & - & - & - & - \\
\hline
\end{tabular}




\begin{tabular}{|c|c|c|c|c|c|c|}
\hline (A) & befluaa & & $\begin{array}{c}\text { Ral IImu-II } \\
\text { Keish }\end{array}$ & $\begin{array}{l}\text { Sosial dan } \\
\text { an }\end{array}$ & & $\begin{array}{l}\text { l. } 2 \text { No. } 1 \\
i \quad \text { Juni } 20 \\
\end{array}$ \\
\hline & & & & & & \\
\hline & & Keadaan & & & & \\
\hline No & Golongan & Laki-laki & & Wanita & & Jumlah \\
\hline & & Dewasa & $\begin{array}{l}\text { Anak- } \\
\text { anak }\end{array}$ & Dewasa & $\begin{array}{l}\text { Anak- } \\
\text { anak }\end{array}$ & \\
\hline 4 & Napi III s & 17 & - & - & - & 17 \\
\hline 5 & Tah A I & 36 & - & 5 & - & 41 \\
\hline 6 & Tah A II & 42 & - & 2 & - & 44 \\
\hline 1 & 2 & 3 & 4 & 5 & 6 & 7 \\
\hline 7 & Tah A III & 81 & 2 & 9 & - & 92 \\
\hline 8 & Tah A IV & - & - & - & - & - \\
\hline 9 & Tah V & - & 1 & - & - & 1 \\
\hline Jum & lah & 538 & 6 & 37 & - & 581 \\
\hline Sun & & $\begin{array}{l}\text { Lem } \\
\text { gsidim }\end{array}$ & & masyar & $\tan$ & las \\
\hline
\end{tabular}

Keterangan:

Kapasitas : 175 orang

Isi $\quad: 581$ orang (data bulan juli 2016)

B-I : Narapidana hukuman di atas 1 tahun

B-II a : Narapidana hukuman 3 bulan -1 tahun

$\mathrm{B}-\mathrm{II} \mathrm{b} \quad$ : Narapidana menjalani hukuman 1 hari -3 bulan

B-III s : Narapidana hukuman kurungan atau pengganti

denda

A-I : Tahanan Kepolisian

A-II : Tahanan Pengadilan

A-III : Tahanan banding tingkat-1

A-IV : Tahanan banding ke pusat

A-V : Tahanan kasasi

Selanjutnya temuan khusus dari penelitian pengamatan dan hasil wawancara dilapangan mengenai pembinaan Narapidana Anak di Lembaga Pemasyarakatan Kelas 2 B Padangsidimpuan

Pembinaan yang dilaksanakan oleh Lembaga Pemasyarakatan Kelas 2 B Padangsidimpuan dalam hal ini terhadap narapidana anak merupakan tugas dan kewajiban pihak lapas dalam membeikan pembinaan terhadap narapidana anak, hasil pengamatan yang ditemukan dilapangan pembinaan yang diberikan hanya di fokuskan pada pembinaan pribadi saja, hal ini menyangkut tentang kehidupan 


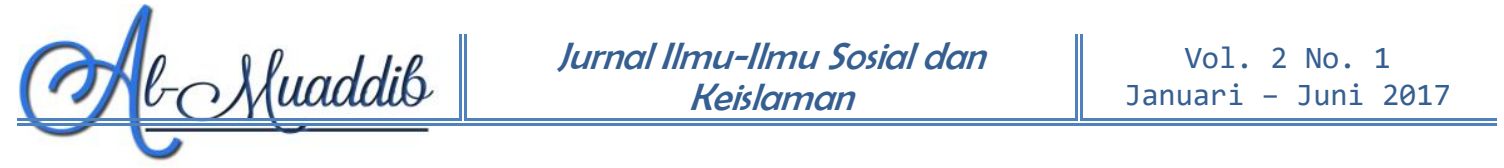

beragama, dimana narapidana anak di berdayakan untuk mengikuti kegiatan agama mereka masing-masing seperti agama Islam mereka dibina untuk dalam hal mengaji, sholat, dan berdakwah.

Narapidana anak juga diberikan siraman-siraman rohani oleh pihak lapas dan kerjasama dengan Kementerian Agama dalam melakukan hal pembinaan keagamaan terhadap narapidana anak tersebut, begitu juga narapidana anak di luar islam. Pembinaannya sesuai dengana agama masig-masing.

Pembinaan kemandirian yang juga merupakan pembinaan yang ada didalam Lembaga Pemasyarakatan Kelas 2 B Padangsidimpuan. Hasil wawancara dan pengamatan dilapangan pembinaan kemandirian tidak begitu berjalan dilaksanakan, ini disebabkan oleh prasaranaa yang masih kurang dan memadai bagi narapidana anak, kegiatan kerja termasuk merupakan pembinaan terhadap narapidana anak mengalami kendala dengan kerja sama yang kurang efektip dengan pihak ke tiga sepeti Dinas Sosial dan KLK selaku rekan kerja Lapas dalam melakukan pembinaan tehadap narapidana anak di Lembaga Pemasyarakatan Kelas 2 B Padangsidimpuan

Kendala yang dihadapi petugas Lapas dalam melaksanakan pembinaan Narapidana Anak yang pertama adalah masalah lingkungan Lembaga Pemasyarakatan, dimana lingkungan yang tidak begitu memadai mengakibatkan Narapidana bisa bergaul dengan Napi dewasa, yang kedua karang memadainya kapasitas di dalam Lapas yang sering disebut dengan over kapasitas membuat potensi dari narapidana anak tidak bisa dikembangkan dengan baik dan yang terakhir ialah kekurangan personil atau petugas lapas, ini mengakibatkan berkurangnya efektipitas petugas dalam melaksanakan tugasnya dalam melakukan pembinaan Narapidana Anak.

Upaya yang dilakukan dalam menghadapi kendala-kendala yang dihadapi yaitu sedang dilaksanakannya tahap pembangunan sarana dan prasarana didalam Lembaga Pemasyaraktan Kelas 2 B 


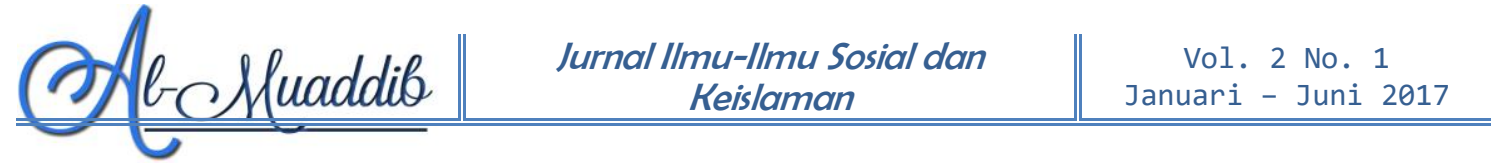

Padangsidimpuan, pembangunan ini diharapkan akan mampu mengurangi keterbatasan sarana dan prasarana didalam lapas, dan mengenai kekurangan personil atau petugas pihak Lapas telah bekerjasama dengan pihak Satpol PP dalam mendukung pelaksanaan tugas didalam Lembaga Pemasyarakatan.

\section{E. PENUTUP}

1. Kesimpulan

Berdasarkan hasil penelitian yang telah dilaksanakan di Lembaga Pemasyarakatan Kelas 2 B Padangsidipuan dapat disimpulkan sebagai berikut:

a. Pembinaan yang diberikan oleh pihak Lembaga Pemasyaraktan Kelas 2 B Padangsidimpuan terhadap narapidana anak hanya terfokus pada pembinaan kepribadian dalam hal ini menyangkut bidang keagamaan. Dimana narapidana anak diharuskan untuk mengikuti kegiatan-kegiatan keagamaan menurut kepercayaan masing-masing. Dalam hal pembinaan kegiatan kerja yang disebut dengan pembinaan kemandirian belum berjalan efektip karena kurangnya kerja sama dengan pihak ke tiga seperti Dinas Sosial dan KLK dan juga prasarana dan sarana yang tidak memadai.

b. Kendala-kendala yang dihadapi oleh petugas Lembaga Pemasyarakatan Kelas 2 B Padangsidimpuan dalam melaksanakan pembinaan terhadap narapidana anak masih sangat banyak, akan tetapi permasalahan yang paling mendasar ialah kapasitas di Lapas yang tidak mencukupi. Kekurangan petugas ini mengakibatkan kurang efektipnya proses pelaksanaan pembinaan terhadap narapidana anak, untuk mengantisipasi ini pihak Lapas telah melakasanakan program pembangunan seluruh ruangan dan penambahan bangunan Lapas terutama di kamar tahanan dan fasilitas umum lainnya. 
Mengenai kekurangan petugas pihak Lapas telah mendapatkan tambahan petugas dari Kementerian Hukum dan Ham dan juga pihak lapas menjalin kerja sama dengan Sat Pol PP Kota Padangsidimpuan.

c. Upaya yang dilakukan lapas dalammelasanakan pembinaan narapidana anak tersebut yaitu, membangun sarana dan prasarana untuk lebih mengefektifkn kegiatan pembinaan. Membangun kerjasama dengan pihak Satpol PP Padangsidimpuan.

\section{Saran}

a. Kepada pihak Lembaga Pemasyarakatan Kelas 2 B Padangsidimpuan agar lebih memperbanyak program pembinaan terhadap narapidana anak tidak hanya terpokus pada pembinaan kepribadian saja akan tetapi pembinaan kemandirian juga merupakan pembinaan yang sangat penting. Memperbanyak jumlah kamar tahanan narapidana, sehingga tidak terjadi over kapasitas di dalam Lembaga.

b. Kepada narapidana anak, agar tidak lagi mengulangi kesalahannya jika nanti keluar dari Lapas.

\section{DAFTAR PUSTAKA}

\section{Buku:}

Arikunto Suharsimi, Prosedur Penelitian Suatu Pendeketan Praktik, Jakarta, 2010.

Angger Sigit Pramukti dan Fuady Primaharsya, Sistem Peradilan Pidana Anak, Yogyakarta: Pustaka Yustisia, 2015.

David J Cooke, Pamela J Baldwin, Jaqueline Hawison, Menyikap Dunia Gelap Penjara, Jakarta: PT Gramedia Pustaka Umum, 2008.

Juhairi Imam, Perlinduangan Hukum terhadap Anak dalam Keluarga Poligami, Jakarta: Pustaka Bangsa, 2003 


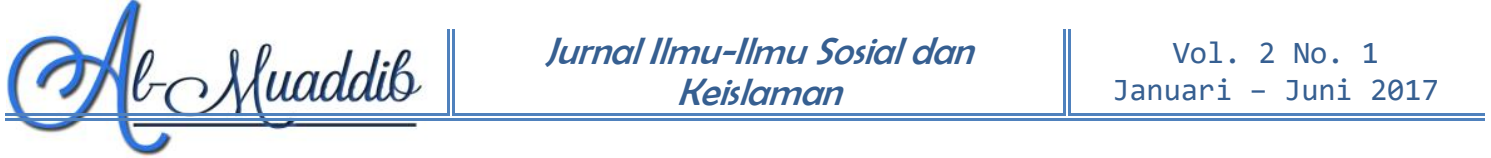

Pusat Bahasa Departemen Pendidikan Nasional, Kamus Bahasa Indonesia, Pusat Bahasa Departemen Pendidikan Nasional, Jakarta, 2004

Majda El Muhtaj, Dimensi-Dimensi HAM, Jakarta: PT RajaGrafindo Persada, 200

M. B. Ali, T. Deli, Kamus Lengkap Bahasa Indonesia, Bandung: Penabur Ilmu, 2000.

Mukthar, Bimbingan Skripsi, Tesis dan Artikel Ilmiah, Jakarta: Gaung Persada Press, 2010.

Nugroho Riant, Public Policy, Kuala Lumpur: PT. Elex Media Komputindo, 2011.

Sutinah dan Bagong Suyanto, Metode Penelitian Sosial, Surabaya: Prenada Media, 2005.

Soedjito dan Bungaran, Metode Penelitian Sosial, Medan: Bina Media Printis, 2009.

Sugiyono, Metode Penelitian Administrasi, Bandung. Alfabeta, 2003.

Sudarsono, Kamus Hukum, Jakarta: PT. Asdi Mahestya, 2009

Sudarsono, Kenakalan Remaja, Jakarta: Rineka Cipta, 2012.

Thoha Miftah, Pembinaan Organisasi, Jakarta: Raja Grafindo Persada.2004.

\section{Undang-Undang dan Peraturan Pemerintah:}

UUD 1945 Pasal 28 B Ayat 2

Undang-Undang Nomor 1 Tahun 1974 Tentang Perkawinan

Undang-Undang Nomor 8 Tahun 1974 Tentang KUHP

Undang-Undang Nomor 12 Tahun 1995 Tentan Pemasyarakatan

Undang-Undang Nomor 3 Tahun 1997 Tentang Pengadilan Anak

Undang-Undang Nomor 39 Tahun 1999 Tentang Hak Asasi Manusia

Undang-Undang Nomor 35 Tahun 2014 Tentang Perlindungan Anak

Kitab Undang-Undang Hukum Perdata Pasal 330

Peraturan Pemerintah Nomo 2 Tahun 1988 Tentang Tata Usaha Kesejahteraan Anak bagi Anak yang Mempunyai Masalah 
Peraturan Pemerintah Nomor 31 Tahun 1999 Tentang Pembinaan dan Pembimbingan warga Binaan Pemasyrakatan

Perpres Republik Indonesia Nomor 59 Tahun 2015 Tentang Kementrian Pemberdayaan Perempuan dan Perlindungan Anak 